\title{
USE OF NEAR INFRARED SPECTROSCOPY TO DISTINGUISH CARBONIZATION PROCESSES AND CHARCOAL SOURCES
}

\author{
Thiago Campos Monteiro ${ }^{1}$, Renato Vieira da Silva ${ }^{2}$, José Tarcísio Lima ${ }^{3}$, Paulo Ricardo Gherardi $\mathrm{Hein}^{4}$, Alfredo Napoli ${ }^{5}$
}

(received: September 28, 2009; accepted: June 30, 2010)

\begin{abstract}
The near infrared spectroscopy (NIRS) has shown a rapid and accurate technique for evaluation of materials of biological origin. The objective of this study was to evaluate the ability of the near infrared (NIR) spectroscopy associated to the Principal Component Analysis (PCA) for the separation of carbonization processes and identification of the origin of the woods used in the carbonizations. Hence, the charcoal of seven species of Eucalyptus and twenty native species from the Cerrado (savannah) of Minas Gerais, Brazil were investigated. The Eucalyptus wood was carbonized in a laboratory furnace and in a 190 $\mathrm{m}^{3}$ industrial rectangular kilns while the wood of native vegetation was carbonized only under laboratory conditions. The samples were grinded for NIR spectra acquirement. The NIR spectra were analyzed by PCA but no cluster were identified allowing discrimination between charcoal produced from native and from Eucalyptus wood. However, the cluster formed in the PCA when using the first derivative NIR spectra permitted to distinguish charcoal produced in different processes of carbonization. Two groups of data for charcoal produced in the industrial rectangular kilns were also observed, suggesting heterogeneity in the carbonization process.
\end{abstract}

Key words: Charcoal origin, NIRS, principal component analysis.

\section{USO DA ESPECTROSCOPIA NO INFRAVERMELHO PRÓXIMO PARA DIFERENCIAR PROCESSOS DE CARBONIZAÇÃo E FONTES DE CARVÃO VEGETAL}

\begin{abstract}
RESUMO: A espectroscopia no infravermelho próximo (NIRS) tem se apresentado uma técnica rápida e precisa para a avaliação de materiais de origem biológica. Objetivou-se, neste trabalho, avaliar a habilidade da espectroscopia no infravermelho próximo, em conjunto com Análise de Componente Principal (PCA), para separação dos processos de carbonização e a identificação de madeiras usadas na carbonização. Para isso foram realizadas carbonizações de sete espécies de Eucalyptus e vinte espécies nativas do Cerrado do estado de Minas Gerais, Brasil. As madeiras de Eucalyptus foram carbonizadas em forno experimental de laboratório e forno industrial de alvenaria com volume de $190 \mathrm{~m}^{3}$, enquanto as madeiras de vegetação nativa foram carbonizadas apenas em condições de laboratório. As amostras foram moídas e submetidas à varredura espectral na região do infravermelho próximo. Os espectros obtidos no NIR foram submetidos à PCA, mas não indicaram nenhum agrupamento que permitisse a diferenciação carvões de madeiras nativas de carvões de Eucalyptus. No entanto, os agrupamentos formados pela PCA através da primeira derivada permitiram diferenciar o carvão obtido nos diferentes processos de carbonização. Também foi possível verificar dois agrupamentos de dados do carvão produzido no forno de alvenaria, pela heterogeneidade do processo de carbonização.
\end{abstract}

Palavras-chave: Origem do carvão vegetal, NIRS, análise de componentes principais.

\section{INTRODUCTION}

The carbonization of wood is the process of thermal decomposition of wood, occurring in the absence or presence of controlled quantities of oxygen, generating a solid residue called charcoal (WENZL, 1970), and the generation of condensed and non- condensable gases. During this process the wood is subjected to the action of heat at relatively high temperatures, undergoing a transformation process in which all components are extensively modified (GOMES \& OLIVEIRA, 1982).

The components modified during carbonization are from cellulose, hemicelluloses, lignin and extractives. The

\footnotetext{
${ }^{1}$ Forest Engineer, Master in Science and Technology of Wood - Laboratório de Ciência e Tecnologia da Madeira - Universidade Federal de Lavras/UFLA - Campus Universitário - Cx.P. 3037 - 37200-000 - Lavras, MG, Brazil - tcmforest@yahoo.com ${ }^{2}$ Forest Engineer, Professor Dr. in Science and Technology of Wood - Departamento de Engenharia Florestal - Universidade Federal do Tocantins/UFT - Campus Universitário de Gurupi - Cx.P. 66 - 77402-970 - Gurupi, TO, Brazil - rsvieira@uft.edu.br

${ }^{3}$ Forest Engineer, Dr. in Forest Science, Professor - Departamento de Ciências Florestais - Universidade Federal de Lavras /UFLA Campus Universitário - Cx.P. 3037 - 37200-000 - Lavras, MG, Brazil - jtlima@ dcf.ufla.br

${ }^{4}$ Forest Engineer, PhD Candidate of Univessity of Montpellier 2 - CIRAD - Production and Processing of Tropical Woods - TA A-40/16, 73 rue Jean-François Breton 34398 Cedex 5 - Montpellier, France - phein1980@ gmail.com

${ }^{5}$ Researcher of CIRAD - PERSYST Department - Tropical Forest Products - Montpellier, France - alfredo.napoli@cirad.fr
}

Cerne, Lavras, v. 16, n. 3, p. 381-390, jul./set. 2010 
behavior of the chemical constituents of wood together with the factors leading to the carbonization process such as heating rate and final temperature should be evaluated for the best homogeneity of charcoal produced.

The chemical components of wood are degraded in different temperature ranges: hemicelluloses between 200 and $380^{\circ} \mathrm{C}$, cellulose from 250 to $380^{\circ} \mathrm{C}$ and lignin between 180 and $900^{\circ} \mathrm{C}$ (GASPAROVIC et al., 2009). Depending on the wood sample size, different temperature ranges can occur simultaneously and, depending on the volume and the oven, carbonization at different temperatures are found along the profile (TRUGILHO \& SILVA, 2001). Thus, one sample of wood can provide the degradation of different components at the same time.

Due to variations occurring during carbonization, the charcoal produced is a heterogeneous chemical compound and in some charcoal it is almost pure carbon, while in others it undergoes a partial carbonization process having significant amounts of oxygen and hydrogen (PINHEIRO et al., 2005). Some studies evaluated the properties of charcoal as a function of final temperature and heating rate. Trugilho \& Silva (2001) evaluated the influence of these parameters in Jatobá (Himenea courbaril) charcoal founding differences in fixed carbon, volatiles, ash and other yields, which depends on the final temperature of carbonization. Pinheiro et al. (2005) studied the influence of temperature and heating rate on the properties of charcoal from Eucalyptus and obtained difference in yields of gravity and fixed carbon content, and the optimum temperature of the carbonization process in the range from 300 to $450^{\circ} \mathrm{C}$ for Eucalyptus and the slower process increased the yield in charcoal.

Charcoal with uniform properties is important when its use is intended for steel mill blast furnaces to produce metal or iron. Features such as the fixed carbon content, volatile matter, ash, moisture, density, porosity, compressive strength, particle size, reactivity and other limiting factors account for the operation of blast furnaces, since the coal during its use has the functions of a fuel element and reducer (SANTOS, 2008). The chemical constituents of charcoal, fixed carbon and volatiles are used in processing iron-ore in metal or iron, and ash content of less than $1 \%$ is embedded in the metal producing impurity (SAMPAIO, 2004).

Quality control analysis of charcoal used in blast furnaces is generally limited due to the large number of samples required, high sampling costs and slowness in obtaining results, making the characterization of the industrial charcoal technically and economically impractical (CAMPOS et al., 2008). Hence, the energy industry requires new solutions for controlling the quality of their charcoal in order to maintain the same quality standard. A suitable technique for characterization a range of materials is near infrared (NIR) spectroscopy (BURNS \& CIURCZAK, 2001). The technique is described by Pasquini (2003) as fast (one minute or less for analysis), non-destructive, applicable to any biological material, including online procedures and it requires minimum or no sample preparation. The association of NIR spectroscopy with multivariate analysis has allowed the study of quantitative and qualitative characteristics on a large scale of samples, covering sectors such as textile industry, fossil fuels, agriculture, food, pharmaceutical and forestry (TSUCHIKAWA, 2007). In forestry researches, this technique has been used as a rapid tool for tree phenotyping in breeding programs (SCHIMLECK, 2008). The main wood traits assessed by NIR spectroscopy are the chemical (SANTOS et al., 2009) and morphological properties (VIANA et al., 2009) and the wood density (HEIN et al., 2009a) due to their high cost for large-scale measurement.

In regard to the charcoal assessment by NIR spectroscopy, there are few works available in the literature. In Brazil, a work was conducted by Barcellos (2007) who assessed the fixed carbon content, volatiles and calorific value of charcoal produced from native species and the genus Eucalyptus by NIR spectroscopy. This author used multiple linear regression and obtained good correlation ( 0.83 to 0.97 ) between the properties determined in the laboratory and the spectral information in the charcoal measurements. Campos et al. (2008) evaluated the performance of NIR spectroscopy combined with multivariate models to estimate the levels of volatiles and fixed carbon of charcoal produced from Eucalyptus. The authors used the partial least squares regression to correlate the levels of volatiles and fixed carbon to the spectral information and found determination of prediction coefficients of 0.85 for volatiles levels and 0.86 for fixed carbon estimate. Campos (2008) showed even more promising results when using more elaborate techniques, such as the selection of more informative wavelengths and application of spectral processing. The author evaluated the charcoal produced from 168 hybrids of Eucalyptus grandis and Eucalyptus urophylla and obtained predictive models with determination coefficient of 0.95 of volatile material content and 0.96 for fixed carbon 
content, indicating that NIR spectroscopy technique can be used to estimate, with accuracy, charcoal properties.

Based on the works of other industries it is believed that this technique has a wide range of applications to be explored for charcoal and energy industry. Just as in the pharmaceutical sector, which uses NIR spectroscopy combined with principal component analysis to identify false medicines (FRASSON SCAFI \& PASQUINI, 2001) and in food industry, which uses these techniques to identify adultered fruit juice (TWOMEY et al., 2006) or adulterants in olive oil (WESLEY et al., 1996), it is suspected that spectra principal component analysis in the near infrared region can be used in charcoal to distinguish species and carbonization processes. Considering the serious environmental problems caused by deforestation of native forests for illegal charcoal production, the application of this technique would be useful to monitor and assist the supervision of charcoal. Currently, there is no fast and safe method to classify and distinguish charcoal origin (wood from native or planted forest) and the process of carbonization which is, according to Mendes et al. (1982), directly related to immediate charcoal chemistry, especially the fixed carbon levels and volatile material in charcoal

Hence, the aim of this study was to evaluate the ability of Near Infrared Spectroscopy associated to the Principal Component Analysis (PCA) to discriminate the carbonization processes and identification of the origin of wood used in carbonization.

\section{MATERIAL AND METHODS}

\subsection{Sampling}

The charcoal used in this work was from Eucalyptus and native species produced by three different carbonization processes, namely: $i$ ) unknown - samples of charcoal were obtained from Eucalyptus in local commerce, produced by unknown processes of carbonization; ii) Industrial furnace - fifteen random samples of charcoal were removed from two industrial FR-190 rectangular kilns, which belong to Vallourec \& Mannesmann (V\&M) Florestal Ltda company, located in Paraopeba, Minas Gerais, Brazil. These industrial kilns are brick made and have nominal capacity to produce 190 cubic meters of charcoal. Their dimensions are $16 \mathrm{~m} \times 4 \mathrm{~m} \times 4.5 \mathrm{~m}$ in length, width and height respectively. As performed by Fávero et al. (2007), Eucalyptus logs of $3.60 \mathrm{~m}$ in length were arranged in four logs piles, parallel to the longitudinal direction of the furnace and kiln. The complete cycle lasted 12 days, going through the steps of loading the logs, ignition, drying, carbonization, cooling and unloading, and after this 15 samples were taken randomly and iii) Laboratory laboratory muffle furnace of the University Federal of Lavras (UFLA muffle furnace) - twenty native trees and seven Eucalyptus trees were used to produce charcoal in an electric furnace of the Biomass Energy Laboratory at the UFLA. There was collected one disk per tree at diameter breast heigh (1.3 meters from the soil) with longitudinal thickness of approximately $4.5 \mathrm{~cm}$ and variable diameter (Table 1).

Discs of native species were provided and identified by the "Minas Gerais Forest Inventory Project - Instituto Estadual de Florestas, MG - UFLA". Discs of Eucalyptus were collected from two trees felled on the campus of UFLA, another three trees were supplied by Gerdau company and other two trees supplied by V\&M Florestal. From the discs opposite wedges were removed for carbonization. Table 1 shows the data for the samples of charcoal obtained in all cases.

\subsection{Parameters of experimental carbonization - UFLA}

The carbonizations were performed in electric muffle furnace adapted with a carbonization capsule as described by Trugilho et al. (2005). The samples were subjected to the final temperature of $450^{\circ} \mathrm{C}$ with a heating rate of $10^{\circ} \mathrm{C} / \mathrm{min}$, and there were two replicates for each species. The charcoal samples were then grinded; homogenized and taken to a climatic room with air temperature of $20^{\circ} \mathrm{C} \pm 2^{\circ} \mathrm{C}$ and relative humidity of $60 \% \pm 5 \%$ staying there until constant mass was obtained.

\subsection{Acquisition of NIR spectra data}

The acquisition of the NIR spectra was performed using a Bruker spectrometer (MPA model, Bruker Optik $\mathrm{GmbH}$, Ettlingen, Germany), operating with its software (OPUS v. 4.2). Fourier transform spectrometer is designed for reflectance analysis of solids with an integrating sphere. Spectral acquisition was performed in diffuse reflection mode in the 4,000 to $12,500 \mathrm{~cm}^{-1}$ range with a spectral resolution of $8 \mathrm{~cm}^{-1}$. A sintered gold standard was used as background. Two NIR spectra were measured for each sample, each NIR spectrum representing an average of 64 readings. The NIR spectra were measured from samples of grinded charcoal. The spectral information was measured in a climatic room with temperature of $20^{\circ} \mathrm{C} \pm 2^{\circ} \mathrm{C}$ and relative humidity of $60 \% \pm 5 \%$. Under these conditions, the equilibrium moisture content of charcoal samples was $12 \%$.

Cerne, Lavras, v. 16, n. 3, p. 381-390, jul./set. 2010 
Table 1 - Species of the carbonized samples, origin, diameter of the discs in centimeters $(\varnothing)$, carbonization process utilized and number of samples (n).

Tabela 1 - Espécie das amostras carbonizadas, procedência, diâmetro dos discos em centímetros (Ø), processo de carbonização utilizado e número de amostras ( $n)$.

\begin{tabular}{|c|c|c|c|c|}
\hline Species & Origin & $\varnothing \mathrm{cm}$ & Carbonization process & $\mathrm{n}$ \\
\hline Eucalyptus sp & Unknown & - & Unknown & 2 \\
\hline Eucalyptus urophylla (clone) & V\&M Florestal & - & Industrial Furnace & 15 \\
\hline Eucalyptus sp (clone) & Gerdau & 16.6 & \multirow{27}{*}{ Laboratory } & 2 \\
\hline Eucalyptus sp (clone) & Gerdau & 14 & & 2 \\
\hline Eucalyptus sp (clone) & Gerdau & 13 & & 2 \\
\hline Eucalyptus urophylla (clone) & V\&M Florestal & 15.6 & & 2 \\
\hline Eucalyptus urophylla (clone) & V\&M Florestal & 14.6 & & 2 \\
\hline Eucalyptu camaldulensis & UFLA & 25 & & 2 \\
\hline Eucalyptus camaldulensis & UFLA & 25.6 & & 2 \\
\hline Bowdichia virgilioides & Thick Savanna & 21.8 & & 2 \\
\hline Copaifera langsdorffii & Thick Savanna & 34 & & 2 \\
\hline Unknown & Thick Savanna & 24 & & 2 \\
\hline Pterodon polygalaeflorus & Thick Savanna & 40.5 & & 2 \\
\hline Tabebuia caraiba & Open Savanna & 25.2 & & 2 \\
\hline Dipteryx alata & Open Savanna & 17 & & 2 \\
\hline Eriotheca gracilipes & Open Savanna & 30 & & 2 \\
\hline Eriotheca pubescens & Open Savanna & 22.4 & & 2 \\
\hline Eriotheca pubescens & Open Savanna & 48 & & 2 \\
\hline Unknown & Open Savanna & 30.2 & & 2 \\
\hline Unknown & Open Savanna & 14 & & 2 \\
\hline Magonia pubescens & Open Savanna & 31 & & 2 \\
\hline Matayba guianensis & Open Savanna & 23.8 & & 2 \\
\hline Myrcia splendens & Open Savanna & 18.2 & & 2 \\
\hline Plathymenia reticulata & Open Savanna & 25.4 & & 2 \\
\hline Pterodron emarginatus & Open Savanna & 23.2 & & 2 \\
\hline Qualea cordata & Open Savanna & 22 & & 2 \\
\hline Qualea grandiflora & Open Savanna & 18 & & 2 \\
\hline Terminalia fagifolia & Open Savanna & 31 & & 2 \\
\hline Unknown & Semideciduous & 18.8 & & 2 \\
\hline Total of samples & & & & 71 \\
\hline
\end{tabular}

\subsection{Principal component analysis parameters}

NIR spectral differences were detected by means of Principal Component Analysis (PCA). PCA was determined with a maximum of twelve major components using the Unscrambler (CAMO AS, Norway) software version 9.7. The tests were verified by full cross-validation method. In order to suppress the noise and improve the quality of the signal, the pre-treatment of the first and second derivative were employed in spectral information. First derivatives (13-point filter and a second order

Cerne, Lavras, v. 16, n. 3, p. 381-390, jul./set. 2010 
polynomial) and second derivatives (25-point filter and a third order polynomial) were applied on the NIR spectra data using Savitzky \& Golay (1964) algorithm. To detect anomalous samples the Student residual and leverage values plot were analyzed, as described in Hein et al. (2009a). Samples rated as anomalous were not included in PCA. The Marten's uncertainty test (WESTAD \& MARTENS, 2000) was used to select the wavenumbers with significant loadings.

\section{RESULTS AND DISCUSSION}

\subsection{NIR spectral information}

NIR spectra measurement was performed in diffuse reflection mode, directly on the material. Figure 1 shows NIR absorption spectra for charcoal and the overlap and combination regions of the absorption bands. The spectra are presented in the range of 4,000 to $12,500 \mathrm{~cm}^{-1}$ and were acquired with a spectral resolution of $8 \mathrm{~cm}^{-1}$. Notes on the first and third harmonic of the presence of absorption peaks are in Figure 1. According to
Giordanengo (2005), the peaks indicated by arrows (Figure 1) correspond to carbon double bonds and connections with aromatic groups. The combinations and first overtone zones of NIR spectra of charcoal are represented mainly by noise and no information can be obtained.

\subsection{Identification of charcoal from native forests and planted forests}

NIR spectral differences between samples are easily visualized by means of two-dimensional scatter plot from Principal Component Analysis (HEIN et al., 2009b). In this study, it was performed PCA in order to identify the samples of charcoal as its origin. Figure 2 shows the scores of principal component (PC) 1 and PC 2 from PCA of the raw spectra of charcoal samples from planted and native forests. For the spectra obtained from the original charcoal, two principal components explain $99 \%$ of the variability of the data analyzed, and $80 \%$ is explained by the PC 1 and $19 \%$ by PC 2. It was not possible to distinguish charcoal of planted forests from charcoal of native forests by means

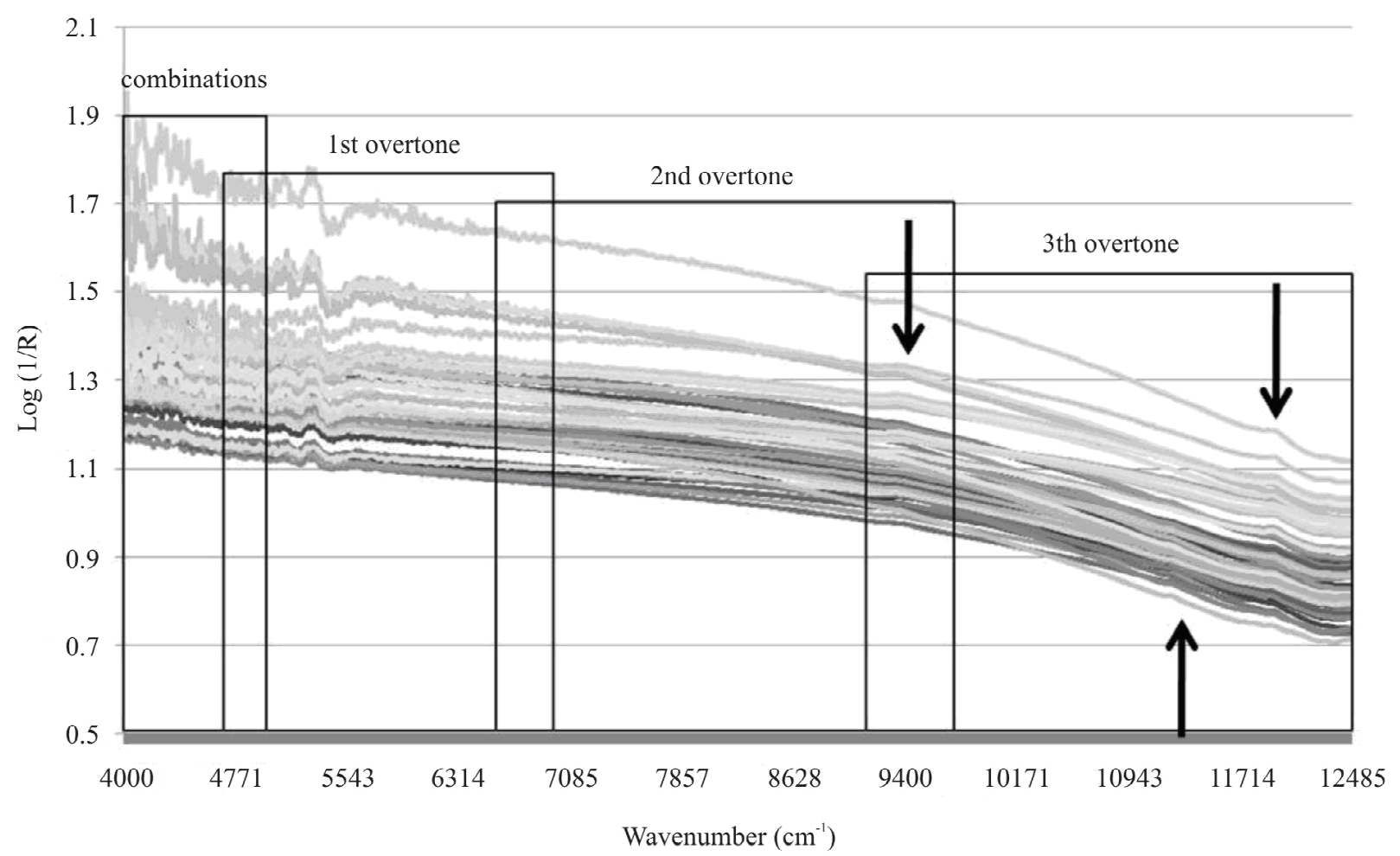

Figure 1 - Near infrared spectra of charcoal and overtones combination regions of the absorption bands.

Figura 1 - Espectros no infravermelho próximo de carvão e regiões de sobreposição e combinação das bandas de absorção.

Cerne, Lavras, v. 16, n. 3, p. 381-390, jul./set. 2010 


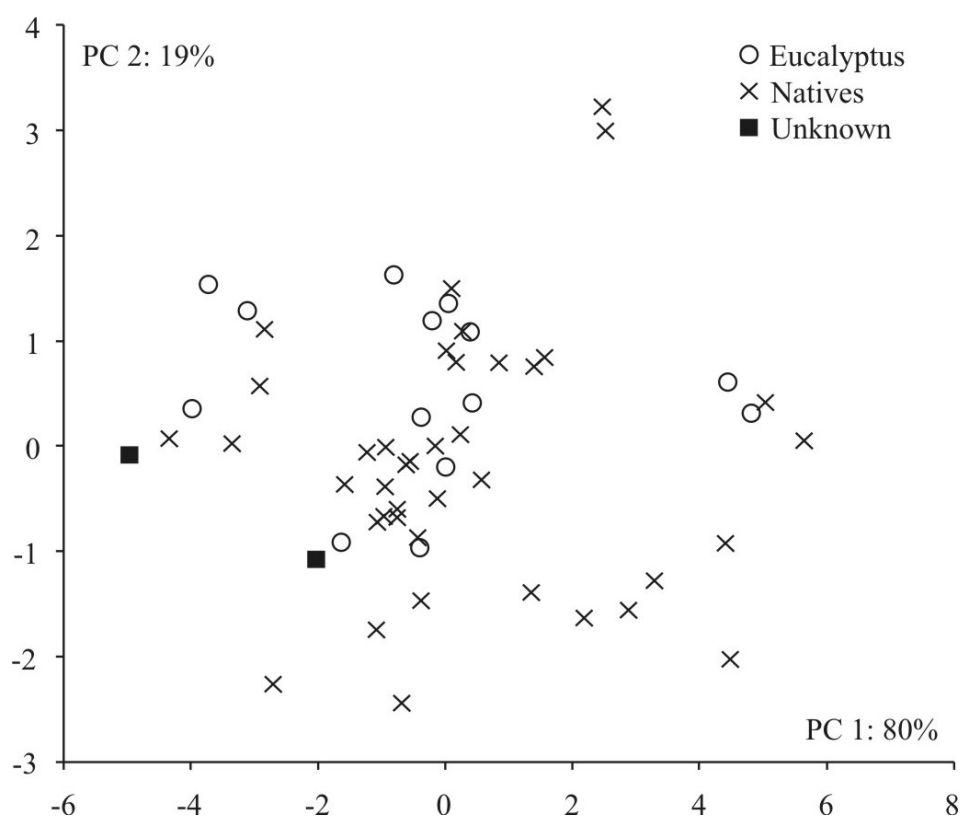

Figure 2 - Bi-dimensional graph of the PC1 and the PC2 scores of raw PCA spectra of charcoal samples from planted and native forests.

Figura 2 - Gráfico bidimensional dos scores da PC1 e PC2 da análise dos componentes principais dos espectros originais das amostras de carvão proveniente de floresta plantada e nativa.

of the PCA of raw spectra. The strong colinearity of charcoal NIR spectra should play a major role on Principal Components Analysis hampering the findings and difficulting its interpretation.

Application of the first derivative on the raw spectral information can reduce the effect of inclination caused on the spectrum baseline (MARTENS \& TORMOD, 1989). Thus, the PCA was also performed on the derivative of the charcoal spectra, with the same aim of separating charcoal from native and planted forests by PCA scores graph. Figure 3 shows PCA scores of charcoal samples obtained on first derivative spectra.

For the first charcoal spectra derivative, two principal components explain only $17 \%$ of data variability, and $9 \%$ is explained by the PC 1 and $8 \%$ by the PC 2 . The remaining $83 \%$ are explained by the components $\mathrm{PC} 3$ to $\mathrm{PC} 12$.

The application of spectral treatment resulted in a large reduction in the ability of PCA to capture the variation among samples (Figure 3). The mathematical treatments on NIR spectra correct the differences in optical path of the light and the difference between the particle sizes of charcoal samples (GIORDANENGO, 2005). For charcoal samples, the first derivative of NIR spectra did not improve the signal and, similarly to the raw NIR spectra (Figure 2), it was not possible to distinguish charcoal of planted forests from that of native forests through the score plot of PC1 and PC2. Physical factors may have contributed to this phenomenon; for instance, differences of size between the particle of charcoal powder and its interaction with the light. It is known that sample preparation influences the information contained within the NIR spectra. Recently, Hein et al. (2010) demonstrated the effect of particle size of the wood powders on the NIR spectra and its implications on multivariate analysis.

\subsection{Separation of carbonization processes}

In order to separate the charcoal samples according to the carbonization process used, the same PCA was performed on the spectral information of charcoal samples. Figure 4 shows the principal component scores PC 1 and PC 2 from raw spectra PCA of charcoal samples produced by the three carbonization processes. 


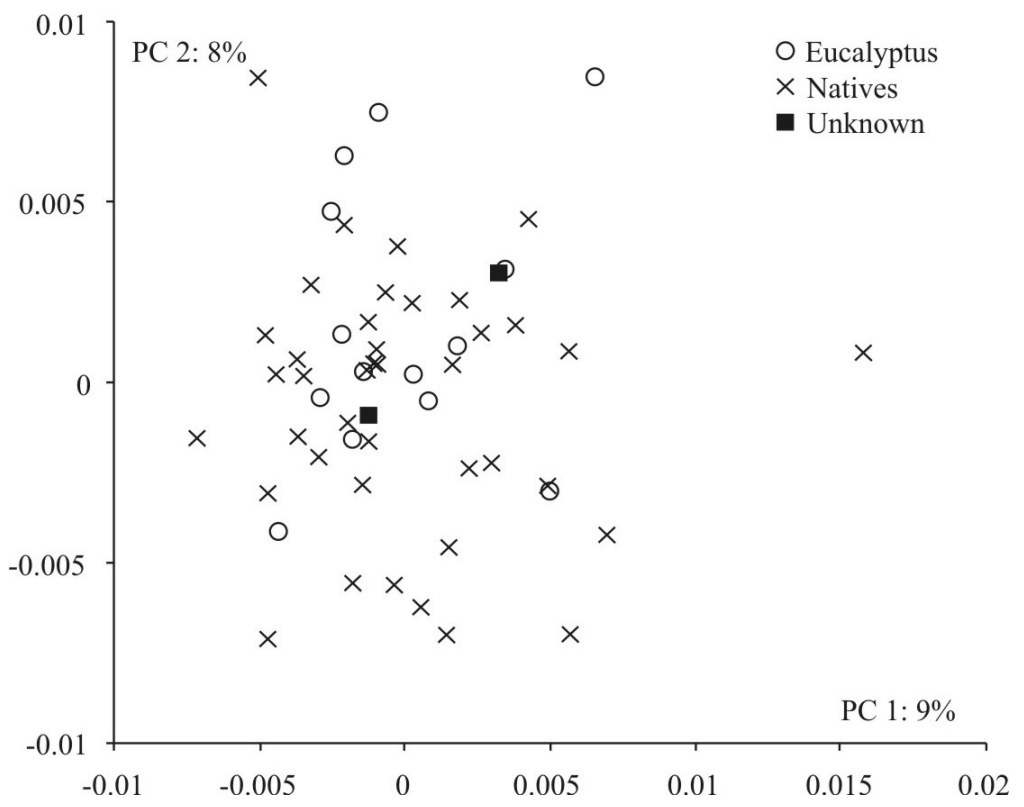

Figura 3 - Bi-dimensional graph of the PC1 and the PC2 scores of PCA first derivative spectra of charcoal samples from planted and native forests.

Figura 3 - Gráfico bidimensional dos scores da PC1 e PC2 da análise dos componentes principais da primeira derivada dos espectros das amostras de carvão proveniente de floresta plantada e nativa.

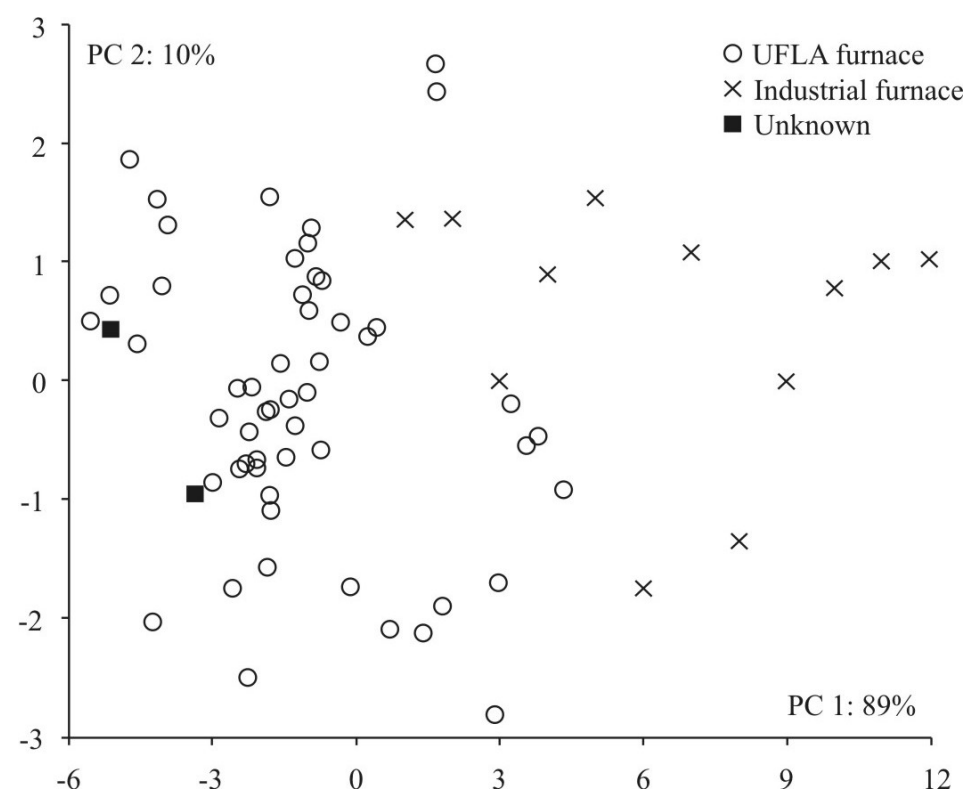

Figure 4 - Bi-dimensional graph of the PC1 and the PC2 scores of raw NIR PCA spectra of charcoal samples produced in experimental and industrial furnaces.

Figura 4-Gráfico bidimensional dos scores da PC1 e PC2 da análise dos componentes principais dos espectros originais das amostras de carvão produzido em forno experimental e industrial.

Cerne, Lavras, v. 16, n. 3, p. 381-390, jul./set. 2010 
For the spectra obtained from the original charcoal samples, similarly to the observed in the first analysis (Figure 2), two principal components explained 99\% of the analyzed data variability; in which PC 1 explain $89 \%$ and PC 2 explain $10 \%$ of the spectral variability. The charcoal samples have some uniformity and it is not possible to distinguish the carbonization process that originated samples by PCA of the raw spectra. However, the first charcoal spectra derivative was able to separate the charcoal samples according to the carbonization process. Figure 5 shows PCA analysis scores of the spectra processed by the first derivative. The first principal component (Figure 5), which explains $80 \%$ of the data variability, associated to the PC2 (19\%), clearly segregates the charcoal produced by the industrial furnace (Group A) and the laboratory furnace (Group B). The charcoal produced at UFLA presented a well defined grouping because it was carried out in the laboratory under highly controlled process.

The grouping of samples from the industrial charcoal showed a scattering due to the factors inherent to the industrial furnace and raw material. According to
Fávero et al. (2007) this process does not provide uniformity in the parameters of temperature and heating rate and others, due to geometric characteristics of the furnace and the wood bed. Pinheiro et al. (2005) comments that it is difficult to precisely control the speed of carbonization in industrial furnaces due to the gas flow field and internal temperature, and because the biomass characteristics such as humidity, diameter, length and position.

Mendes et al. (1982) showed that the levels of fixed carbon and volatiles from charcoal vary with the place where the charcoal was produced inside the furnace. The same author also pointed out that the immediate chemistry of the charcoal is controlled, among other factors by the carbonization process. In our study, the carbonization process was considered as the responsible for the differences observed between groups A and B.

Samples of commercial charcoal, from planted forests, but with an unknown carbonization process were grouped among the charcoal produced in the laboratory furnace UFLA (Group B). It is important to note that this group includes charcoal produced from planted and native forests wood.

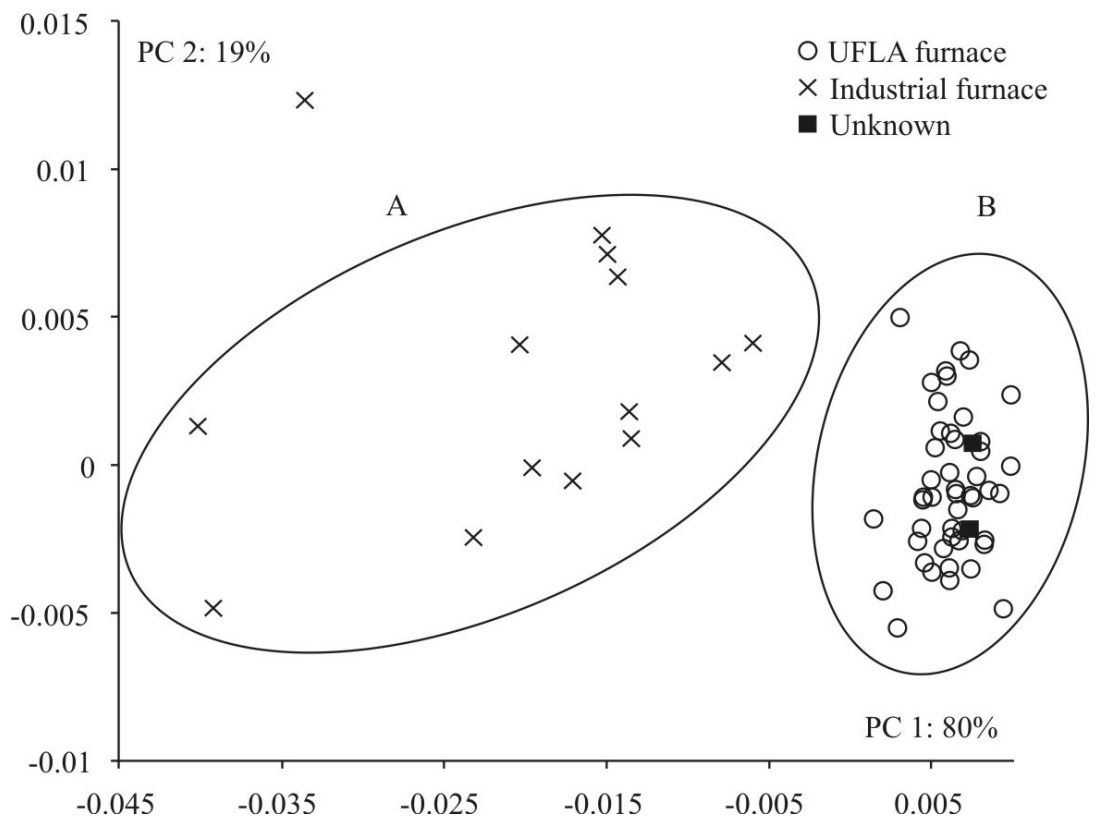

Figure 5 - Bi-dimensional graph of the PC1 and the PC2 scores of PCA of the first derivative spectra of charcoal samples produced in experimental and industrial furnaces.

Figura 5 - Gráfico bidimensional dos scores da PC1 e PC2 da análise dos componentes principais da primeira derivada dos espectros das amostras de carvão produzido em forno experimental e industrial.

Cerne, Lavras, v. 16, n. 3, p. 381-390, jul./set. 2010 


\section{CONCLUSIONS}

The results obtained in this experimental program suggest that the principal component analysis of the charcoal spectra - after pretreatment of the first derivative is a promising technique in the evaluation of charcoal quality.

The technique was able to separate charcoal in two groups, according to carbonization process: industrial or laboratorial one. In regard to the industrial process, two groups were obtained probably due to the geometric characteristics and volume of the oven as well as the heterogeneity of the raw material.

It was not possible to detect the source of charcoal (from native or planted forest) by the principal components analysis of spectral information.

The results presented in this preliminary work indicate that the association of near infrared spectroscopy with multivariate techniques of qualitative analysis is promising to distinguish charcoal from information contained in near infrared spectrum. Therefore, further studies are required to generate a better understanding about these issues.

\section{ACKNOWLEDGMENTS}

The authors would like to thank CAPES and CNPq for providing financial support, and The "Projeto Inventário Florestal de Minas Gerais" and the company V\&M Florestal for providing wood and charcoal samples to carry out our tests.

\section{BIBLIOGRAPHICAL REFERENCES}

BARCELLOS, D. C. Caracterização do carvão vegetal através do uso de espectroscopia no infravermelho próximo. 2007. 129 p. Tese (Doutorado em Ciência Florestal) - Universidade Federal de Viçosa, Viçosa, 2007.

BURNS, D.; CIURCZAK, E. W. Handbook of near-infrared analysis. 2. ed. New York: M. Dekker, 2001.

CAMPOS, A. C. M. Carvão de Eucalyptus: Efeitos dos parâmetros da pirólise sobre a madeira e seus componentes químicos e predição da qualidade pela espectroscopia NIR. 2008. 118 p. Dissertação (Mestrado em Ciência e Tecnologia da Madeira) - Universidade Federal de Lavras, Lavras, 2008.

CAMPOS, A. C. M.; HEIN, P. R. G.; VIEIRA, R. da S.; TRUGILHO, P. F.; NAPOLI, A.; CHAIX, G. Aplicação da espectroscopia NIR na estimativa da análise química imediata do carvão vegetal. In: SIMPÓSIO DE CIÊNCIA E TECNOLOGIA
DA MADEIRA DO RIO DE JANEIRO, 1., 2008, Seropédica. Anais... Seropédica: UFRJR, 2008. v. 1.

FÁVERO, G. C.; VALLE, R. M.; DUARTE, T. M. Análise térmica de um sistema de combustão de alcatrão em fornos retangulares para secagem da madeira. In: CONGRESSO IBEROAMERICANO DE ENGENHARIA MECANICA, 8., 2007, Cusco. Anais... Cusco, 2007. CD-ROM.

FRASSON SCAFI, S. H.; PASQUINI, C. Identification of counterfeit drugs using near-infrared spectroscopy. Analyst, v. 126, n. 12, p. 2218-2224, 2001.

GAŠPAROVIÈ, L.; KOREÒOVÁ, Z.; JELEMENSKÝ, L. Kinetic study of wood chips decomposition by TGA. In: INTERNATIONAL CONFERENCE OF SSCHE, 36., Tatransk'e Matliare. Proceedings... Tatransk e Matliare, 2009. p. 178-192.

GIORDANENGO, T. Influence de l'humidité du bois sur la performance de l'étalonnage en spectroscopie proche infrarouge. Montpellier: ENGREF, 2005. 106 p.

GOMES, P. A.; OLIVEIRA, J. B. Teoria da carbonização da madeira. In: PENEDO, W. R. (Eds.). Uso da madeira para fins energéticos. Belo Horizonte: CETEC, 1982. p. 27-41.

HEIN, P. R. G.; CAMPOS, A. C. M.; TRUGILHO, P. F.; LIMA, J. T.; CHAIX, G. Near infrared spectroscopy for estimating wood basic density in Eucalyptus urophylla and E. grandis. Cerne, Lavras, v. 15, n. 2, p. 133-141, 2009a.

HEIN, P. R. G.; CHAIX, G.; LIMA, J. T. Effects of sample preparation on NIR spectroscopic estimation of chemical properties of Eucalyptus urophylla S.T. Blake wood. Holzforschung, Berlin, v. 64, p. 45-54, 2010.

HEIN, P. R. G.; LIMA, J. T.; CHAIX, G. Robustness of models based on near infrared spectra to predict the basic density in Eucalyptus urophylla wood. Journal of Near Infrared Spectroscopy, v. 17, n. 3, p. 141-150, 2009 b.

MARTENS, H. E.; TORMOD, N. Multivariate calibration. New York: J. Wiley, 1989.

MENDES, M. G.; GOMES, P. A.; OLIVEIRA, J. B. Propriedades e controle da qualidade do carvão vegetal. In: PENEDO, W. R. Produção e utilização de carvão vegetal. Belo Horizonte: CETEC, 1982. p. 77-89.

Cerne, Lavras, v. 16, n. 3, p. 381-390, jul./set. 2010 
PASQUINI, C. Near infrared spectroscopy: fundamentals, practical aspects and analytical applications. Journal of the Brazilian Chemical Society, v. 14, n. 2, p. 198-219, 2003.

PINHEIRO, P. C. C.; FIGUEIREDO, F. J.; SEYE, O. Influência da temperatura e da taxa de aquecimento da carbonização nas propriedades do carvão vegetal de Eucalyptus. Biomassa \& Energia, São Paulo, v. 2, n. 2, p. 159-168, 2005.

SAMPAIO, R. S. Agente redutor na produção de metais: exemplo do eucalipto na produção de ferro-gusa. Biomassa \& Energia, São Paulo, v. 1, n. 2, p. 145-155, 2004.

SANTOS, M. A. S. Parâmetros de qualidade do carvão vegetal para uso em alto-forno. In: FÓRUM NACIONAL SOBRE CARVÃO VEGETAL, 1., 2008, Belo Horizonte. Anais... Belo Horizonte, 2008. CD-ROM.

SANTOS, R. B.; GOMIDE, J. L.; SOUSA, L. C. Predição de qualidade da madeira e da polpa celulósica por técnica de espectroscopia de infravermelho próximo (NIRS). Revista Árvore, Viçosa, v. 33, n. 4, p. 759-767, 2009.

SAVITZKY, A.; GOLAY, M. J. E. Smoothing and differentiation of data by simplified least-squares procedures. Analytical Chemistry, n. 36, p. 1627-1639, 1964.

SCHIMLECK, L. R. Near-infrared spectroscopy: a rapid nondestructive method for measuring wood properties, and its application to tree breeding. New Zealand Journal of Forestry Science, v. 38, n. 1, p. 14-35, 2008.

TRUGILHO, P. F.; SILVA, D. A. da. Influência da temperatura final de carbonização nas características físicas e químicas do carvão vegetal de Jatobá (Himenea courbaril L.). Scientia Agraria, Piracicaba, v. 2, n. 1/2, p. 45-53, 2001.

TRUGILHO, P. F.; SILVA, J. R. M.; MORI, F. A.; LIMA, J. T.; MENDES, L. M.; MENDES, L. F. B. Rendimentos e características do carvão vegetal em função da posição radial de amostragem em clones de Eucalyptus. Cerne, Lavras, v. 11, n. 2, p. $178-186,2005$.

TSUCHIKAWA, S. A review of recent near infrared research for wood and paper. Applied Spectroscopy Review, v. 42, p. 43-71, 2007.

TWOMEY, M.; DOWNEY, G.; MCNULTY, P. B. The potential of NIR spectroscopy for the detection of the adulteration of orange juice. Journal of the Science of Food and Agriculture, Washington, v. 67 n. 1, p. 77-84, 2006.

VIANA, L. C.; TRUGILHO, P. F.; HEIN, P. R. G.; LIMA, J. T.; SILVA, J. R. M. Prediction of morphological characteristics and basic density of Eucalyptus wood by NIRS technic. Cerne, Lavras, v. 15, n. 4, p. 421-429, 2009.

WENZL, H. F. J. The chemical technology of wood. New York: Academic, 1970. 692 p.

WESLEY, I. J.; PACHECO, F.; MCGILL, A. E. J. Identification of adulterants in olive oils. Journal of the American Oil Chemists' Society, Madison, v. 73, n. 4, p. 1558-1565, 1996.

WESTAD, F.; MARTENS, F. Variable selection in near infrared spectroscopy based on significance testing in partial least square regression. Journal of Near Infrared Spectroscopy, v. 8, p. 117-124, 2000. 